\title{
Sense of Coherence, Coping and Burnout of Pharmacists
}

\section{Basson}

Human Resources Department, S. Buys Pharmacy Group, Carletonville

\section{S Rothmann}

Programme in Industrial Psychology, Potchefstroom University for CHE

\section{ABSTRACT}

People in almost any occupation could develop burnout. The objective of this research was to determine the relationship between sense of coherence, coping and burnout in a corporate pharmacy group. A cross-sectional survey design was used. The study population consisted of 67 pharmacists. The Maslach Burnout Inventory, Orientation to Life Questionnaire and COPE were administered. The results showed that sense of coherence is significantly related to emotional exhaustion, depersonalisation and personal accomplishment. Regarding coping strategies, mental disengagement was positively related to emotional exhaustion and depersonalisation, while positive reinterpretation and restraint coping were positively related to personal accomplishment. Sense of coherence and coping strategies explained 44 per cent, 35 per cent and 41 per cent of the variance in emotional exhaustion, depersonalisation and personal accomplishment respectively.

JEL J00

\section{INTRODUCTION}

The environment in which pharmacists currently function demands more of them than during any previous period. Pharmacists have to cope with the demands that arise from fulfilling various roles, as well as with increased pressures such as managed health care and primary health care (Davidson, 1998). It is therefore of great importance to track and address their effectiveness in coping with new demands (Gupchup, Singhal, Dole \& Lively, 1998). One area that should be researched in this regard is bumout.

Burnout as a phenomenon was originally observed primarily among people helpers such as nurses, social workers and police workers. However, today it is acknowledged that people in almost any occupation could develop burnout (Dubrin, 1990). Burnout is a syndrome of emotional exhaustion and cynicism 
that occurs frequently among individuals who do "people-work" of some kind (Maslach, 1982b). It is accompanied by an array of helplessness and hopelessness, disillusionment, negative self-concept, negative attitudes toward work, people and life itself (Maslach \& Jackson, 1986).

The consequences of burnout are potentially serious for staff, clients, and the larger institutions in which they interact. Maslach and Jackson (1986) suggested that bumout could lead to deterioration in the quality of care or service that is provided by the staff. It appears to be a factor in job turnover, absenteeism, and low morale. Furthermore, it correlates with various self-reported indices of personal dysfunction, increased use of alcohol and drugs, and marital and family problems (Maslach \& Jackson, 1986). Managers suffering from burnout could hurt the organisation because they spread it to their subordinates (DuBrin, 1990).

Golembiewski, Boudreau, Munzenrider and Luo (1996) summarised more than 60 North American studies that included almost 25000 participants ranging from accountants and managers, through nurses, clerks and production workers, to students of police academies and MBA-programmes. Overall, 20 per cent are categorised in the most severe phase of burnout, with percentages ranging from study to study between 0 per cent and 35 per cent. They concluded that the estimates of burnout in various occupations are "far too high for anyone's comfort" (op. cit.: 165). Golembiewski et al. (1996) also listed more than 20 studies that were performed outside North America where it was found that burnout rates were even higher in most of the samples.

According to Gupchup et al. (1998), burnout among pharmacists can have severe adverse implications, including reduced quality of care, absenteeism, low organisational commitment, tumover and job dissatisfaction. It was found pharmacists experience a moderate level of burnout. Möller, Rothmann, Coetzer and Rothmann (2000) expressed concern that a pattern of introversion, neuroticism, a practical approach and inflexibility, combined with situational demands, role overload and pharmacists' responsibility for management and care, may result in burnout and eventually impairment. Therefore, research regarding the burnout levels of pharmacists in a corporate pharmacy environment and correlates thereof seems relevant and necessary. 


\section{THEORETICAL BACKGROUND}

\subsection{Burnout}

Schaufeli and Enzmann (1998: 36) define bumout as "a persistent, negative, work-related state of mind in 'normal' individuals that is primarily characterised by exhaustion, which is accompanied by distress, a sense of reduced effectiveness, decreased motivation, and the development of dysfunctional attitudes and behaviours at work. This psychological condition develops gradually but may remain unnoticed for a long time by the individual involved. It results from a misfit between intentions and reality in the job. Often burnout is self-perpetuating because of inadequate coping strategies that are associated with the syndrome".

Stress should not be confused with burnout. According to Schaufeli and Enzmann (1998), bumout can be considered as a particular kind of prolonged job stress. An individual experiences job stress when the demands of the workplace exceed his of her adaptive responses. Burnout is a particular, multidimensional, chronic stress reaction that goes beyond the experience of mere exhaustion. Bumout is seen as the final step in a progression of unsuccessful attempts to cope with a variety of negative stress conditions.

Burnout also differs from depression. Burnout occurs in a context of anger rather than guilt and is situation-specific rather than pervasive. Depression is characterised by a generalisation of an individual's symptoms across all situations and spheres of life, whereas bumout is regarded as job-related. Individuals who are burned-out at work may function normally in respect of their private life. Although the emotional exhaustion component of burnout is related to depression, the relationship of depression with other burnout components is less strong (Schaufeli \& Enzmann, 1998).

Burnout is conceptualised by Maslach (1982b) as a syndrome consisting of three interrelated but conceptually distinct characteristics, namely emotional exhaustion, depersonalisation and low personal accomplishment:

- Emotional exhaustion describes a reduction in the emotional resources of an individual. When asked how they feel, burned-out employees typically answer that they feel drained or used up and physically fatigued.

- Depersonalisation refers to an increase in negative, cynical and insensitive attitudes towards colleagues, clients and/or patients.

- Low personal accomplishment refers to a feeling of being unable to meet clients' needs and to satisfy essential elements of job performance. 
Schaufeli and Enzmann (1998) analysed 73 studies and found that the levels of emotional exhaustion for six occupational fields were significantly higher than the cut-off points provided by Maslach, Jackson and Leiter (1996). This tendency is attributed to the increase in overall job demands during the past decade. In the field of medicine, physicians and nurses experience about the same level of emotional exhaustion, but physicians have much higher scores on depersonalisation, whereas nurses experience a strongly reduced sense of personal accomplishment (Schaufeli \& Enzmann, 1998). Furthermore, teachers experience high levels of emotional exhaustion, while physicians and police officers experience high levels of depersonalisation.

The symptoms of a burnout sufferer can be categorised as follows (DuBrin, 1990; Schaufeli \& Enzmann, 1998):

- $\quad$ Affective symptoms. Individuals who suffer from burnout show a tearful and depressed mode. The individual's emotional resources are exhausted because too much energy has been used for too long a time. His or her emotional control might be decreased which can lead to undefined fears, anxiety and nervous tension. Burned-out individuals can be irritable and oversensitive, but also cool and unemotional. Bursts of angers may occur and their job satisfaction is low.

- Cognitive symptoms. The burned-out individual feels helpless, hopeless and powerless. Work loses its meaning and a sense of failure is experienced. The individual may not be able to concentrate for a long period, is forgetful and makes all kind of minor mistakes. Thinking becomes rigid, while emotional and personal issues and problems are intellectualised. Decision-making becomes more difficult and the individual may run away from reality by daydreaming and fantasising. At interpersonal level there is a decreased involvement with recipients, which is evident in negativism, pessimism, hostility, suspicion, lessened empathy and stereotyping.

Physical symptoms. Three categories of physical symptoms are observed in burned-out individuals. Firstly, all kinds of indefinite physical distress complaints are observed, for example headaches, nausea, dizziness, restlessness, muscle pains, hyperventilation, sexual problems, sleep disturbances, sudden loss or gains of weight and chronic fatigue. Secondly, psychosomatic disorders like ulcers, gastric-intestinal disorders, coronary heart disease, prolonged colds and flu and susceptibility to viral infections are observed. Thirdly, a number of physiological reactions are observed, for example increased heart rate and respiration rate, hypertension and high levels of serum cholesterol. 
- Behavioural symptoms. The burned-out individual tends to be hyperactive, but does not know what to do or where to go. He or she acts impulsively without carefully considering altemative options. On the other hand, procrastination, doubt and decisiveness are also observed. The consumption of stimulants, like coffee and tobacco increases, as may the use of alcohol, tranquillisers, barbiturates or drugs. Over- and undereating and accident proneness are also observed. At interpersonal level, the individual tends to be aggressive or tends to social isolation and withdrawal. At organisational level, burnout is characterised by reduced effectiveness, poor work performance and minimal productivity.

- Motivational symptoms. The burned-out individual's intrinsic motivation vanishes: enthusiasm, interest and idealism are lost. By contrast, disillusionment, disappointment and resignation set in. At an interpersonal level the motivational crisis is expressed by a loss of genuine interest in recipients, indifference and discouragement. Work motivation is poor, there is a strong resistance to go to work and the individual's initiative is dampened.

Possible causes of burnout can be classified into personality characteristics, work-related attitudes, and work and organisational characteristics. Organisational factors which contribute to burnout are work overload (Corrigan et al., 1994; Landsbergis, 1988), poor collegial support (Golembiewski \& Munzenrider, 1988), role conflict and role ambiguity (Miller, Ellis, Zook \& Lyles, 1990) and lack of feedback (participation in decision making and autonomy). Regarding work related attitudes, high (unrealistic) expectations are related to burnout (Schaufeli \& Enzmann, 1998).

Burnout is observed more often among younger employees compared with those older than 30 or $\mathbf{4 0}$ years. Furthermore, burnout is negatively related to work experience. Künzel and Schulte (1986) interpret the greater incidence of burnout in younger and less experienced employees in terms of reality shock, while Cherniss (1980a) regards it as an indicator of an identity crisis due to unsuccessful occupational socialisation. Maslach et al. (1996) show that burnout symptoms decline with growing age or work experience. However, Schaufeli and Enzmann (1998) wam that a selection effect ("survival" bias) might explain the decline of burnout symptoms: "... those who burn out early in their careers are likely to quit their jobs, leaving behind the survivors who exhibit low levels of bumout".

Women tend to score higher on emotional exhaustion, whereas men score higher on depersonalisation. According to Schaufeli and Enzmann (1998), this can partly be explained by sex role-dependent stereotypes. For example, men 
hold instrumental attitudes, whereas women are more emotionally responsive and seem to disclose emotions and health problems more easily. Furthermore, due to additional responsibilities at home, working women experience higher workloads compared with men. Workload, in turn, is positively related to bumout, particularly to emotional exhaustion.

Unmarried people (especially men) seem to be more prone to burnout compared with those who are married. However, it is possible that age or psychosocial problems may influence this proneness (Schaufeli \& Enzmann, 1998). Cash (1988) found that individuals with a higher level of education were more prone to burnout than less educated employees. This could be attributed to the higher expectations of the more educated individuals. Another explanation might be that the more highly educated individuals (compared with less educated individuals) more often gain positions with more responsibility (Schaufeli \& Enzmann, 1998).

According to Schaufeli and Enzmann (1998), personality characteristics of employees are related to burnout. Personality hardiness, a confrontational coping style, self-esteem, and extroversion are negatively related to burnout, while an external control orientation, Type $\mathrm{A}$ behaviour and neuroticism are positively related to burnout. The tendency to perceive everits and circumstances as stressful, ways of coping with them and how failure in coping is dealt with, depend in part on the dispositional characteristics of a person. These characteristics involve one's beliefs about the world and possibilities of dealing with it (Semmer, 1996), and include constructs such as sense of coherence (Antonovsky, 1987), personality hardiness (Kobasa, 1982) and locus of control (Rotter, 1966). For the purposes of this research, the focus is on employees' sense of coherence and coping and the possible relationship thereof with burnout.

\subsection{Sense of coherence}

Sense of coherence is a construct from a salutogenic (Antonovsky, 1987) or fortigenic (Strumpfer, 1995) paradigm. The salutogenic paradigm focuses on the origins of health in terms of an ease/disease continuum, while the fortigenic paradigm focuses on the strengths of individuals. These paradigms are in contrast with a pathogenic approach, which focuses on the origins of illness.

Sense of coherence is defined as "a global orientation that expresses the extent to which one has a pervasive, enduring though dynamic, feeling of confidence that one's internal and external environments are predictable and that there is a high probability that things will work out as well as can reasonably be expected" (Antonovsky, 1987: xiii). The definition of sense of coherence 
includes three dimensions which represent the concept, that is comprehensibility, manageability and meaningfulness (Antonovsky, 1987).

- Comprehensibility refers to the extent to which one perceives stimuli from the internal and external environment as information that is ordered, structured and consistent. The stimuli are perceived as comprehensible and make sense on a cognitive level.

- Manageability refers to the extent to which individuals experience events in life as situations that are endurable or manageable and can even be seen as new challenges.

- Meaningfulness refers to the extent to which one feels that life is making sense on an emotional and not just a cognitive level.

According to Antonovsky (1987) there is good theoretical reason and empirical evidence for expecting the three components to be inextricably intertwined. Antonovsky (1987) mentions that one's sense of coherence is tried continually but individuals who developed a strong sense of coherence early in adulthood have the ability to use general resistance resources to restore equilibrium. Sense of coherence can thus be viewed as a stable dispositional orientation.

A strong sense of coherence is negatively related to measures of negative affectivity, such as anxiety and neuroticism (Flannery \& Flannery, 1990; Frenz, Carey \& Jorgenson, 1993) and work stress (Feldt, 1997). A strong sense of coherence is also related to competence and life satisfaction (Kalimo \& Vuori, 1990), general well-being (Feldt, 1997), emotional stability (Mlonzi \& Strümpfer, 1998) and successful coping with life stress (Flannery, Perry, Penk \& Flannery, 1994; McSherry \& Holm, 1994). According to Antonovsky (1987), a high level of sense of coherence should enable a person to apply a wide range of coping strategies flexibly. Tyler and Cushway (1998) found that more stressed workers make more use of all types of coping strategies.

Levert, Lucas and Ortlepp (2000) reported significant correlation coefficients between two components of burnout (emotional exhaustion and depersonalisation) and sense of coherence in a group of psychiatric nurses in South Africa. Their results showed that whether psychiatric nursing staff believed they had the resources available to meet the demands of their environment, the extent to which these demands were seen as challenges worthy of engagement, and the degree to which the environment was regarded as structured and predictable related to whether they will experience emotional exhaustion and depersonalisation components of bumout. Gilbar (1998) found significant correlation coefficients between social workers' sense of coherence and emotional exhaustion $(r=-0.30)$ as well as sense of coherence and personal accomplishment $(r=-0.34)$. 
An individual with a strong sense of coherence will be more inclined to understand the nature and dimensions of an acute or chronic stressor and will define it as something that he or she can cope with. He or she will regard it as manageable by using resources within his or her own or others' control rather than becoming helpless. However, sense of coherence on its own, without the appropriate ability, skills, training and development, would be of no avail (Strümpfer, 1990).

\subsection{Coping}

Kleinke (1991: 3) defines coping as "the efforts we make to manage situations we have appraised as potentially harmful or stressful". Coping refers to perceptual, cognitive or behavioural responses that are used to manage, avoid or control situations that could be regarded as difficult (Folkman \& Lazarus, 1984; Moos, 1994; Zeidner \& Endler, 1996). The term "coping" could be used to refer to either strategies or results (Fleishman, 1984). As a strategy, coping refers to the different methods that a person may apply to manage his or her circumstances. As a result, coping refers to the eventual outcomes of this strategy for the person. For the purposes of this research, the focus is on coping as a strategy.

Callan (1993) defines non-coping as failed efforts to cope, accompanied by various physical and psycho-social disturbances, which result in higher stress. Non-copers experience that things do not make sense and they lose perspective on issues. Carver, Scheier and Weintraub (1989) mention that non-coping results in higher levels of depression and anxiety. These characteristics are negatively related to sense of coherence (Mlonzi \& Strümpfer, 1998).

Amirkhan (1994), Callan (1993) and Folkman and Lazarus (1980) distinguish between problem-focused and emotion-focused coping. Problem-focused coping is directed at eliminating an unpleasant experience or reducing the effects thereof. Emotion-focused coping is directed at reducing the effects of stressful feelings caused by an unpleasant experience through relaxation, the use of alcohol and drugs, social activities and/or defence mechanisms.

Carver et al. (1989) distinguish between five variations of problem-focused coping, namely:

- Active coping (taking active steps to remove stressors or to reduce their effects).

- Planning (thinking about various strategies which could be used to solve a problem).

- Suppressing competing activities (moving other projects temporarily to the background). 
- Restraint coping (waiting for the right opportunity to solve a problem rather than acting impulsively).

- Seeking social support for instrumental reasons (looking for advice, support or information).

Furthermore, Carver et al. (1989) distinguish between the following five variations of emotion-focused coping:

- Seeking social support for emotional reasons (reaching out to others for moral support, sympathy and understanding).

- Positive reinterpretation (managing stress emotions rather than the stressors by reinterpretation).

- Denial (experiencing stressors as unreal).

- Acceptance (accepting stressors as a reality).

- Turning to religion (focusing on religion to facilitate emotional support, positive reinterpretation as well as active coping).

Carver et al. (1989) distinguish the following coping strategies that are used less:

- Focus on and venting of emotions (focusing on a stressful situation and expressing feelings about it).

- Behavioural disengagement (ignoring and avoiding stressors and becoming more helpless and powerless).

- Mental disengagement (excessive sleeping or daydreaming to get away from stressors).

- Alcohol-drug disengagement (using alcohol or drugs to manage stress).

In the literature high levels of burnout are associated with ineffective (Rowe, 1997) or withdrawal coping strategies and low degrees of burnout with constructive coping strategies (Maslach \& Jackson, 1982). Rowe (1997) also demonstrated the importance of teaching individuals with limited coping skills to alter the way in which they address problems. Alsoofi, Al-Heeti and Alwashli (2000) found a significant correlation between ways of coping and burnout.

Individuals who are burned-out cope with stressful events in a rather passive, defensive way, whereas individuals who use confronting coping strategies experience less burnout (Schaufeli \& Enzmann, 1998). Both confronting and avoiding coping share about 5-10 per cent of the variance of emotional exhaustion and depersonalisation. With respect to personal accomplishment, confronting coping explains 15 per cent of variance, whereas the relationship with avoiding coping is weaker. The use of a problem-focused strategy may trigger feelings of personal accomplishment, which could explain the 
relationship of confronting coping with personal accomplishment (Lee \& Ashforth, 1996).

The objective of this research was to establish the relationship between burnout, sense of coherence and coping in a corporate pharmacy group. If a relationship between burnout, sense of coherence and coping of pharmacists in the corporate environment could be found, it may have implications for their recruitment, induction, selection, training, development and performance management.

\section{METHOD}

\subsection{Research design}

A survey design was used to reach the research objectives. The specific design is the cross-sectional design, whereby a sample is drawn from a population at a specific time (Shaughnessy \& Zechmeister, 1997).

\subsection{Participants}

The study population consisted of all retail, hospital and executive pharmacists $(\mathrm{N}=67)$ in a corporate pharmacy group. A total of 56.72 per cent are married, while 25.37 per cent have been working for the company for longer than two years.

\subsection{Measuring battery}

The Maslach Burnout Inventory (MBI) (Maslach \& Jackson, 1986) was used to determine participants' level of bumout. The MBI consists of three sub-scales, namely Emotional Exhaustion, Depersonalisation and Personal Accomplishment (Maslach \& Jackson, 1981, 1986). The three sub-scales of the MBI were dealt with separately in this study, based on considerable factor-analytical support for their separation (Maslach \& Jackson, 1986; Schaufeli \& Janczur, 1994). Maslach and Jackson (1981, 1986) and Lahoz and Mason (1989) reported Cronbach alpha coefficients varying from 0.71 to 0.90 for the three sub-scales of the MBI. Test-retest reliability varied from 0.60 to 0.82 and 0.54 to 0.60 (applied after one year). External validation of the MBI comes from analyses of its convergence with peer ratings, job dimensions associated with burnout, and stress outcomes (Maslach \& Jackson, 1984).

The Orientation to Life Questionnaire (OLQ) (Antonovsky, 1987) was used to measure participants' sense of coherence. The OLQ consists of 29 items. Antonovsky (1993) reported alpha coefficients of the OLQ in 29 research 
studies varying between 0.85 and 0.91 . Test-retest reliability studies found coefficients between 0.41 and 0.97 (Antonovsky, 1993). Rothmann (2000) reported an alpha coefficient of 0.89 for the OLQ, which may be regarded as acceptable (Nunnally \& Bernstein, 1994). Regarding the construct validity of the OLQ, it was found that there is a negative relationship between the OLQ and experienced stress and that the OLQ correlates negatively with the "StateTrait Anxiety Inventory-Trait" and the "Beck Depression Inventory" (Frenz et al., 1993).

The COPE Questionnaire (COPE) (Carver et al., 1989) was used to measure participants' coping strategies. The COPE is a multidimensional 53-item coping questionnaire that indicates the different ways in which people cope in different circumstances (Carver et al., 1989). It measures 13 different coping strategies. Five sub-scales (four items each) measure different aspects of problem-focused coping: Active Coping, Planning, Suppressing of Competing Activities, Restraint Coping and Seeking Social Support for Instrumental Reasons. Five sub-scales (four items each) measure aspects of emotion-focused coping: Seeking Social Support for Emotional Reasons, Positive Reinterpretation and Growth, Acceptance, Denial and Turning to Religion. Four sub-scales indicate coping responses that are used less: Focus on and Venting of Emotions, Behavioural Disengagement, Mental Disengagement and Alcohol-drug Disengagement (Carver et al., 1989). Carver et al. (1989) reported Cronbach alpha coefficients varying from 0.45 to 0.92 . All the sub-scales have sufficient levels of reliability except for Mental Disengagement, which measures lower than 0.60 . Test-retest reliability varies from 0.46 to 0.86 and 0.42 to 0.89 (applied after two weeks).

\subsection{Statistical analysis}

The statistical analysis was carried out with the help of the SAS-program (SAS Institute, 1996). Cronbach alpha coefficients, inter-item correlation coefficients and confirmatory factor analysis were used to assess the reliability and validity of the measuring instruments (Clark \& Watson, 1995). Descriptive statistics (e.g. means, standard deviations, skewness and kurtosis) were used to analyse the data. Because a non-probability sample was used in this research, effect sizes (rather than inferential statistics) were used to decide on the significance of the findings. Pearson product-moment correlation coefficients were used to specify the relationships between the variables. A cut-off point of 0.30 (medium effect) (Cohen, 1988) was set for the practical significance of correlation coefficients.

A stepwise multiple regression analysis was conducted to determine the percentage of the variance in the dependent variables (coping and bumout) that 
effect size (which indicates practical significance) in the case of multiple regression is given by the following formula (Steyn, 1999):

$f^{2}=R^{2} /\left(1-R^{2}\right)$.

A cut-off point of 0.35 (large effect) (Steyn, 1999) was set for the practical significance of $f^{2}$.

\section{RESULTS}

Table I shows the descriptive statistics, the Cronbach alpha coefficients and the average inter-item correlation coefficients of the MBI, OLQ and COPE.

Table 1 Descriptive statistics, alpha coefficients and inter-item correlation coefficients of the MBI, OLQ and Cope

\begin{tabular}{|c|c|c|c|c|c|c|c|}
\hline Item & Mean & SD & Range & $\begin{array}{l}\text { Skew- } \\
\text { ness }\end{array}$ & $\begin{array}{l}\text { Kurto- } \\
\text { sis }\end{array}$ & $\begin{array}{c}\mathbf{r} \\
\text { (Mean) }\end{array}$ & $\alpha$ \\
\hline \multicolumn{8}{|c|}{ MBI } \\
\hline $\begin{array}{l}\text { Emotional } \\
\text { Exhaustion }\end{array}$ & 14.69 & 9.91 & 41.00 & 0.68 & -0.19 & 0.51 & 0.89 \\
\hline Depersonalisation & 5.21 & 4.90 & 19.00 & 1.10 & 0.56 & 0.31 & 0.67 \\
\hline $\begin{array}{l}\text { Personal } \\
\text { Accomplishment }\end{array}$ & 38.89 & 5.96 & 26.00 & 0.86 & 0.31 & 0.26 & 0.73 \\
\hline \multicolumn{8}{|c|}{ OLQ } \\
\hline Comprehensibility & 51.37 & 7.90 & 34.00 & -0.12 & -0.40 & 0,20 & 0.73 \\
\hline Manageability & 52.76 & 8.38 & $34.00^{\circ}$ & -0.53 & -0.58 & 0.33 & 0.83 \\
\hline Meaningfulness & 47.07 & 5.74 & 23.00 & -0.48 & -0.56 & 0.42 & 0.85 \\
\hline Total & $\begin{array}{r}151.2 \\
1\end{array}$ & 19.53 & 81.00 & -0.37 & -0.62 & & \\
\hline \multicolumn{8}{|c|}{ COPE } \\
\hline Active Coping & 12.42 & 2.10 & 10.00 & -0.23 & 0.22 & 0.25 & 0.56 \\
\hline Planning & 13.63 & 2.23 & 11.00 & -1.16 & 2.30 & 0.41 & 0.73 \\
\hline $\begin{array}{l}\text { Suppressing } \\
\text { Competition }\end{array}$ & 10.45 & 2.20 & 12.00 & -0.22 & 0.33 & 0.26 & 0.58 \\
\hline Restraint Coping & 11.03 & 2.59 & 12.00 & -0.14 & 0.09 & 0.36 & 0.68 \\
\hline
\end{tabular}


Table 1 continued

\begin{tabular}{|l|r|r|r|r|r|r|c|c|}
\hline \multicolumn{1}{|c|}{ Item } & Mean & SD & Range & $\begin{array}{c}\text { Skew- } \\
\text { ness }\end{array}$ & $\begin{array}{c}\text { Kurto- } \\
\text { sis }\end{array}$ & $\begin{array}{c}\text { r } \\
\text { Mean })\end{array}$ & $\alpha$ \\
\hline $\begin{array}{l}\text { Seeking Social } \\
\text { Support - IR }\end{array}$ & 11.72 & 2.89 & 12.00 & -0.53 & -0.32 & 0.57 & 0.84 \\
\hline $\begin{array}{l}\text { Seeking Social } \\
\text { Support - ER }\end{array}$ & 10.88 & 3.49 & 12.00 & -0.06 & -1.12 & 0.64 & 0.88 \\
\hline $\begin{array}{l}\text { Positive } \\
\text { Reinterpretation }\end{array}$ & 13.54 & 1.90 & 8.00 & -0.43 & -0.30 & 0.35 & 0.67 \\
\hline Acceptance & 11.55 & 2.22 & 10.00 & 0.08 & 0.03 & 0.32 & 0.64 \\
\hline $\begin{array}{l}\text { Turning to } \\
\text { Religion }\end{array}$ & 13.87 & 2.75 & 12.00 & -1.61 & 2.35 & 0.63 & 0.86 \\
\hline $\begin{array}{l}\text { Focus on / Venting } \\
\text { Emotions }\end{array}$ & 8.60 & 2.94 & 12.00 & 0.84 & 0.38 & 0.52 & 0.81 \\
\hline Denial & 5.60 & 1.94 & 11.00 & 2.01 & 7.08 & 0.27 & 0.56 \\
\hline $\begin{array}{l}\text { Behavioural } \\
\text { Disengagement }\end{array}$ & 5.70 & 1.61 & 5.00 & 0.80 & -0.47 & 0.16 & 0.42 \\
\hline $\begin{array}{l}\text { Mental } \\
\text { Disengagement }\end{array}$ & 8.19 & 2.08 & 7.00 & 0.24 & -0.56 & 0.13 & 0.36 \\
\hline $\begin{array}{l}\text { Alcohol-drug } \\
\text { Disengagement }\end{array}$ & 1.09 & 0.34 & 2.00 & 4.09 & 17.72 & - & - \\
\hline $\begin{array}{l}\text { Note } \\
\text { Ding }\end{array}$ & & & & & & \\
\hline
\end{tabular}

\section{Note}

- Low Personal Accomplishment scores imply high burnout levels;

- Emotional Exhaustion scores $\leq 16$ are 'low'; 17-26 are 'average'; and scores $\geq 27$ are 'high';

- Depersonalisation scores $\leq 6$ are 'low'; 7-12 are 'average'; and scores $\geq 13$ are 'high';

- Personal Accomplishment scores $\leq 31$ are 'high'; 32-38 are 'average'; and scores $\geq 39$ are 'low'.

Table 1 shows Cronbach alpha coefficients varying from 0.67 to 0.89 for the MBI. Although the alpha coefficient of Depersonalisation is somewhat lower than the cut-off point recommended by Nunnally and Bernstein (1994), the coefficients are acceptable. The average inter-correlation between the items is also acceptable $(0.15 \leq \mathrm{r} \leq 0.50$; Clark \& Watson, 1994). Factor analysis confirmed the factor structure of the MBI. Compared with the norms provided by Maslach and Jackson (1986), the scores of pharmacists are low to average. 
The scores on the MBI are relatively normally distributed, with low skewness and kurtosis.

A classification of the levels of burnout (high, moderate or low) of pharmacists as measured by the three scales of the MBl is given in Table 2.

Table 2 Classification of pharmacists' MBI scores

\begin{tabular}{|l|c|c|}
\hline \multicolumn{1}{|c|}{ Item } & Frequency & Percentage \\
\hline High & 9 & 13.43 \\
\hline Moderate & 17 & 25.37 \\
\hline Low & 41 & 61.19 \\
\hline \multicolumn{3}{|c|}{ Depersonalisation } \\
\hline High & 7 & 10.45 \\
\hline Moderate & 12 & 17.91 \\
\hline Low & 48 & 71.64 \\
\hline \multicolumn{3}{|c|}{} \\
\hline High & Personal Accomplishment & \\
\hline Moderate & 43 & 64.18 \\
\hline Low & 15 & 22.39 \\
\hline
\end{tabular}

Table 2 indicates that 13.43 per cent of the pharmacists show high levels of emotional exhaustion. A total of 25.37 per cent of the pharmacists show moderate levels of emotional exhaustion. Regarding depersonalisation, Table 2 shows that 10.45 per cent of the pharmacists show high levels of depersonalisation. Furthermore, 17.91 per cent of the pharmacists show moderate levels of depersonalisation. Table 2 further shows that 13.43 per cent of the pharmacists show low levels of accomplishment. A total of 22.39 per cent of the pharmacists show moderate levels of personal accomplishment. It is clear from Table 2 that most of the pharmacists experience relatively low levels of emotional exhaustion and depersonalisation and high levels of personal accomplishment.

The product-moment correlation coefficients between the OLQ and the COPE are reported in Table 3. 
Table 3 Product-moment correlation coefficients between the OLQ and the Cope

\begin{tabular}{|l|c|c|c|c|}
\hline \multicolumn{1}{|c|}{ Item } & $\begin{array}{c}\text { SOC- } \\
\text { Comprehen } \\
\text {-sibility }\end{array}$ & $\begin{array}{c}\text { SOC- } \\
\text { Manage- } \\
\text { ability }\end{array}$ & $\begin{array}{c}\text { SOC - } \\
\text { Meaningful- } \\
\text { ness }\end{array}$ & $\begin{array}{c}\text { SOC - } \\
\text { Total }\end{array}$ \\
\hline Active Coping & 0.24 & $0.33^{*}$ & 0.24 & $0.31^{*}$ \\
\hline Planning & $0.30^{*}$ & $0.32^{*}$ & 0.23 & $0.33^{*}$ \\
\hline $\begin{array}{l}\text { Suppressing } \\
\text { Competition }\end{array}$ & 0.18 & 0.21 & 0.18 & 0.22 \\
\hline Restraint Coping & $0.39^{*}$ & $0.50^{* *}$ & 0.29 & $0.46^{*}$ \\
\hline $\begin{array}{l}\text { Seeking Social } \\
\text { Support - IR }\end{array}$ & -0.03 & -0.07 & -0.06 & -0.06 \\
\hline $\begin{array}{l}\text { Seeking Social } \\
\text { Support - ER }\end{array}$ & -0.05 & -0.02 & -0.05 & -0.04 \\
\hline $\begin{array}{l}\text { Positive } \\
\text { Reinterpretation }\end{array}$ & 0.29 & $0.44^{*}$ & $0.50^{* *}$ & $0.46^{*}$ \\
\hline Acceptance & 0.24 & 0.07 & 0.12 & 0.16 \\
\hline Turning to Religion & 0.05 & 0.17 & 0.13 & 0.13 \\
\hline $\begin{array}{l}\text { Focus on / Venting } \\
\text { Emotions }\end{array}$ & $-0.34^{*}$ & -0.26 & -0.16 & $-0.30^{*}$ \\
\hline Denial & -0.10 & -0.09 & -0.11 & -0.12 \\
\hline $\begin{array}{l}\text { Behavioural } \\
\text { Disengagement }\end{array}$ & -0.06 & -0.26 & -0.22 & -0.20 \\
\hline $\begin{array}{l}\text { Mental } \\
\text { Disengagement }\end{array}$ & -0.29 & -0.12 & -0.13 & -0.21 \\
\hline $\begin{array}{l}\text { Alcohol-drug } \\
\text { Disengagement }\end{array}$ & -0.01 & -0.15 & -0.16 & -0.14 \\
\hline
\end{tabular}

** Practically significant correlation (large effect): $d \geq 0.50$

* Practically significant correlation (medium effect): $d \geq 0.30$

Table 3 shows that sense of coherence (total) is positively related to active coping, planning, restraint coping, positive reinterpretation (all medium effects). Sense of coherence (total) is also negatively related to focus on and venting of emotions (medium effect). 
The product-moment correlation coefficients between the OLQ and the $\mathrm{MBI}$ are given in Table 4.

Table 4 Product-moment correlation coefficients between the OLQ and the MBI

\begin{tabular}{|l|c|c|c|}
\hline \multicolumn{1}{|c|}{ Item } & $\begin{array}{c}\text { Emotional } \\
\text { Exhaustion }\end{array}$ & $\begin{array}{c}\text { Depersonali- } \\
\text { sation }\end{array}$ & $\begin{array}{c}\text { Personal } \\
\text { Accomplishment }\end{array}$ \\
\hline $\begin{array}{l}\text { SOC - } \\
\text { Comprehensibility }\end{array}$ & $-0.45^{*}$ & $-0.32^{*}$ & 0.29 \\
\hline $\begin{array}{l}\text { SOC - } \\
\text { Manageability }\end{array}$ & $-0.56^{* *}$ & $-0.38^{*}$ & $0.48^{*}$ \\
\hline $\begin{array}{l}\text { SOC - } \\
\text { Meaningfulness }\end{array}$ & $-0.47^{*}$ & $-0.38^{*}$ & $0.55^{* *}$ \\
\hline SOC - Total & $-0.56^{* *}$ & $-0.41^{*}$ & $0.48^{*}$ \\
\hline
\end{tabular}

** Practically significant correlation (large effect): $d \geq 0.50$

* Practically significant correlation (medium effect): $d \geq 0.30$

Table 4 shows that emotional exhaustion is negatively related to individuals' sense of coherence (total score; large effect). Emotional exhaustion is also negatively related to the components of sense of coherence, including Manageability (large effect), Comprehensibility (medium effect) and Meaningfulness (medium effect). Furthermore, it seems from Table 4 that depersonalisation is negatively related to Sense of Coherence (total score) as well as its components, namely Comprehensibility, Manageability and Meaningfulness (all medium effects). Lastly, Table 4 shows that personal accomplishment is related to Sense of Coherence (total score; medium effect) as well as Manageability (medium effect) and Meaningfulness (large effect).

Table 5 shows the product-moment correlation coefficients between the Cope and the $\mathrm{MBI}$. 
Table 5 Product-moment correlation coefficients between the Cope and the MBI

\begin{tabular}{|l|c|c|c|}
\hline \multicolumn{1}{|c|}{ Item } & $\begin{array}{c}\text { Emotional } \\
\text { Exhaustion }\end{array}$ & $\begin{array}{c}\text { Depersona- } \\
\text { lisation }\end{array}$ & $\begin{array}{c}\text { Personal } \\
\text { Accomplishment }\end{array}$ \\
\hline Active Coping & -0.23 & -0.09 & 0.19 \\
\hline Planning & -0.20 & -0.17 & 0.17 \\
\hline $\begin{array}{l}\text { Suppressing } \\
\text { Competition }\end{array}$ & -0.08 & 0.02 & 0.18 \\
\hline Restraint Coping & -0.25 & -0.19 & $0.39^{*}$ \\
\hline $\begin{array}{l}\text { Seeking Social } \\
\text { Support - IR }\end{array}$ & 0.21 & 0.12 & -0.04 \\
\hline $\begin{array}{l}\text { Seeking Social } \\
\text { Support - ER }\end{array}$ & 0.24 & 0.16 & -0.10 \\
\hline $\begin{array}{l}\text { Positive } \\
\text { Reinterpretation }\end{array}$ & -0.29 & -0.21 & $0.54^{* *}$ \\
\hline Acceptance & -0.05 & -0.07 & 0.10 \\
\hline Turning to Religion & -0.20 & -0.27 & 0.18 \\
\hline $\begin{array}{l}\text { Focus on / Venting } \\
\text { Emotions }\end{array}$ & 0.29 & 0.16 & -0.14 \\
\hline Denial & -0.12 & -0.11 & -0.07 \\
\hline $\begin{array}{l}\text { Behavioural } \\
\text { Disengagement }\end{array}$ & 0.18 & 0.01 & $-0.33^{*}$ \\
\hline $\begin{array}{l}\text { Mental } \\
\text { Disengagement }\end{array}$ & $0.38^{*}$ & $0.34^{*}$ & 0.01 \\
\hline $\begin{array}{l}\text { Alcohol-drug } \\
\text { Disengagement }\end{array}$ & 0.08 & 0.29 & -0.03 \\
\hline
\end{tabular}

** Practically significant correlation (large effect): $d \geq 0.50$

* Practically significant correlation (medium effect): $d \geq 0.30$

Table 5 shows that the emotional exhaustion and depersonalisation sub-scales correlate positively with Mental Disengagement (medium effects). The personal accomplishment sub-scale correlates positively with Positive Reinterpretation (large effect) as well as Restraint Coping (medium effect). The personal accomplishment sub-scale also correlates negatively but significantly with Behavioural Disengagement. No other practically significant correlation coefficients were found between burnout and coping strategies. 
The results of a stepwise regression analysis with the sense of coherence and coping strategies as independent variables and emotional exhaustion (as measured by the MBI) are shown in Table 6.

Table 6 Regression analysis of sense of coherence and coping as independent variables and emotional exhaustion as dependent variable

\begin{tabular}{|l|l|l|c|c|c|}
\hline \multicolumn{7}{|c|}{ Analysis of variance } \\
\hline$R^{2}=0.44$ & $\begin{array}{l}\text { Source of } \\
\text { variance }\end{array}$ & $\begin{array}{l}\text { Degrees of } \\
\text { freedom }\end{array}$ & Sum of squares & Mean square \\
\hline $\mathrm{R}=0.66$ & Regression & 3 & 2837.69 & 945.90 \\
\hline$F=16.38$ & $f^{2}=0.79^{\circ}$ & Residual & 63 & 3638.73 & 57.76 \\
\hline \multicolumn{7}{|c|}{ Variables in the equation } \\
\hline Independent Variables & Parameter & $\begin{array}{l}\text { Standard } \\
\text { error }\end{array}$ & $F$ & $p$ \\
\hline Intercept & & 49.59 & 14.65 & 27.58 & 0.0001 \\
\hline Sense of Coherence & -0.27 & 0.05 & 29.14 & 0.0001 \\
\hline Denial & -1.21 & 0.49 & 6.09 & 0.0163 \\
\hline Mental Disengagement & 1.46 & 0.47 & 9.92 & 0.0025 \\
\hline
\end{tabular}

* Practically significant: $f^{2} \geq 0.35$ (large effect)

Table 6 demonstrates that the independent variables (including sense of coherence and coping strategies) predict a total of 44 per cent of the variance in emotional exhaustion of pharmacists (as measured by the MBI). The multiple correlation of 0.66 is practically significant (large effect) $\left(f^{2}=0.79\right.$ ).

The results of a stepwise regression analysis with sense of coherence and coping strategies as independent variables and depersonalisation (as measured by the MBI) as dependent variable are shown in Table 7. 
Table 7 Regression analysis of sense of coherence and coping as independent variables and depersonalisation as dependent variable

\begin{tabular}{|l|l|l|l|c|c|}
\hline \multicolumn{5}{|c|}{ Analysis of variance } \\
\hline$R^{2}=0.35$ & $\begin{array}{l}\text { Source of } \\
\text { variance }\end{array}$ & $\begin{array}{l}\text { Degrees of } \\
\text { freedom }\end{array}$ & Sum of squares & Mean square \\
\hline$R=0.59$ & Regression & 5 & 559.82 & 111.96 \\
\hline$F=6.66$ & $f^{2}=0.54^{*}$ & Residual & 61 & 1025.25 & 16.81 \\
\hline \multicolumn{7}{|c|}{ Variables in the equation } \\
\hline Independent Variables & Parameter & $\begin{array}{l}\text { Standard } \\
\text { Error }\end{array}$ & $t$ & $p$ \\
\hline Intercept & 17.64 & 5.56 & 10.06 & 0.0024 \\
\hline Sense of Coherence & -0.08 & 0.03 & 9,21 & 0.0035 \\
\hline Turning to Religion & -0.36 & 0.19 & 3.71 & 0.057 \\
\hline Denial & -0.56 & 0.27 & 4.36 & 0.0410 \\
\hline Mental Disengagement & 0.59 & 0.26 & 5.00 & 0.0290 \\
\hline $\begin{array}{l}\text { Alcohol-Drug } \\
\text { Disengagement }\end{array}$ & 2.96 & 1.62 & 3.33 & 0.0728 \\
\hline
\end{tabular}

* Practically significant: $f^{2} \geq 0.35$ (large effect)

Table 7 demonstrates that the independent variables (including sense of coherence and coping strategies) predict a total of 35 per cent of the variance in depersonalisation of pharmacists (as measured by the MBI). The multiple correlation of 0.59 is practically significant (large effect) $\left(f^{2}=0.54\right.$ ).

The results of a stepwise regression analysis with the sense of coherence and coping strategies as independent variables and personal accomplishment (as measured by the $\mathrm{MBI}$ ) as dependent variable are shown in Table 8. 
Table 8 Regression analysis of sense of coherence and coping strategies as independent variables and personal accomplishment as dependent variable

\begin{tabular}{|l|l|l|c|c|c|}
\hline \multicolumn{5}{|c|}{ Analysis of variance } \\
\hline$R^{2}=0.41$ & $\begin{array}{l}\text { Source of } \\
\text { variance }\end{array}$ & $\begin{array}{l}\text { Degrees of } \\
\text { freedom }\end{array}$ & Sum of squares & Mean square \\
\hline$R=0.64$ & Regression & 3 & 958.90 & 319.63 \\
\hline$F=14.49$ & $f^{2}=0.70^{\circ}$ & Residual & 63 & 1389.37 & 22.05 \\
\hline \multicolumn{5}{|c|}{ Variables in the equation } \\
\hline Independent Variables & Parameter & $\begin{array}{l}\text { Standard } \\
\text { Error }\end{array}$ & $F$ & $p$ \\
\hline Intercept & 14.46 & 6.07 & 5.68 & 0.0202 \\
\hline Sense of Coherence & 0.08 & 0.03 & 5.93 & 0.0177 \\
\hline $\begin{array}{l}\text { Positive Reinterpretation and } \\
\text { Growth }\end{array}$ & 1.21 & 0.34 & 12.43 & 0.0008 \\
\hline Behavioural Disengagement & -0.76 & 0.37 & 4.16 & 0.0456 \\
\hline
\end{tabular}

* Practically significant: $f^{2} \geq 0.35$ (large effect)

Table 8 demonstrates that the independent variables (including sense of coherence and coping strategies) predict a total of 41 per cent of the variance of personal accomplishment of pharmacists (as measured by the $\mathrm{MBI}$ ). The multiple correlation of 0.64 is practically significant (large effect) $\left(f^{2}=0.79\right.$ ).

\section{DISCUSSION}

Based on the standardised categorisation of burnout levels for sub-scale scores proposed by Maslach and Jackson (1986), the pharmacists in this sample experience low to moderate levels of burnout on the emotional exhaustion and depersonalisation sub-scales. However, it seems that approximately 39 per cent of the pharmacists experience moderate to high levels of emotional exhaustion. This implies a reduction in the emotional resources of an individual, which is accompanied by a feeling of being drained as well as being physically fatigued. A total of 28 per cent of the pharmacists experience moderate to high levels of depersonalisation. This implies negative, cynical and insensitive attitudes towards colleagues, clients and/or patients. The results of pharmacists in this study confirm the findings of Gupchup et al. (1998) that pharmacists experience 
a moderate level of burnout. Daily demands of the job and dealing with patients, the professional role, counter prescribing and time pressures may contribute to emotional exhaustion and depersonalisation.

Pharmacists experience a relatively high level of personal accomplishment, with only 36 per cent who experience low to moderate levels of personal accomplishment. In general, they feel that they are able to meet clients' needs and to satisfy essential elements of job performance. Gupchup et al. (1998) also found that on the personal accomplishment sub-scale, pharmacists' scores indicated a low level of burnout. The evidence of high personal accomplishment levels seems to correlate with satisfaction reported by pharmacists working in the corporate pharmacy group (Rothmann, Rothmann, Van Rensburg \& Malan, 2000).

The sense of coherence of the current sample was found to be above average compared to other samples analysed by Rothmann (2000). A strong sense of coherence is promoted by life experiences which are the results of generalised resistance resources (Antonovsky, 1987). Regarding coping strategies, the current sample was found to score the highest on planning, active coping, positive reinterpretation and turning to religion. They scored the lowest on alcohol-drug disengagement, denial and behavioural disengagement.

Pharmacists with a strong sense of coherence will experience less burnout. This is so because the stronger the sense of coherence, the greater the tendency to identify the nature of the stressor confronted and select the appropriate resources for the given situation. More specifically, the findings indicate that a weak sense of coherence (and especially manageability) is strongly related to emotional exhaustion. Pharmacists who do not experience events in life as manageable, who do not perceive stimuli from the environment as ordered and structured and do not feel that life is making sense tend to experience a reduction in their emotional resources and feel emotionally drained. These components are also related to negative, cynical and insensitive attitudes towards colleagues, clients and/or patients. Meaningfulness is most strongly related to personal accomplishment (i.e. a feeling of being able to meet clients' needs and satisfy essential elements of job performance), although total sense of coherence and manageability are also related to personal accomplishment. It is interesting to note that the pharmacists with a strong sense of meaningfulness believe that the professional demands encountered are challenges worthy of investment and management and consequently will feel more accomplishment and less burnout.

The results show that a strong sense of coherence is related to constructive coping. It seems that a strong sense of coherence is related to the use of 
problem-focused coping strategies such as active coping (taking direct steps to solve problems), planning (thinking about steps to handle stressors) and restraint coping (waiting for the optimal opportunity which will reward appropriate action). A strong sense is positively related to one emotion-focused coping strategy, namely positive reinterpretation. Therefore, pharmacists with a strong sense of coherence will tend to accept the reality and manage stress emotions by positive reinterpretation. However, pharmacists with a strong sense of coherence will be less inclined to cope by just expressing their feelings about stressful situations.

Pharmacists who cope by mentally disengaging themselves from situations experience more emotional exhaustion and depersonalisation. Mental disengagement implies that they engage in activities such as excessive sleeping and daydreaming, which divert their attention from stressors. However, by denying the reality of situations, it becomes more difficult to cope with them later on (Carver et al., 1989). Although other problem-focused coping strategies (e.g. active coping, planning and restraint coping) are negatively related to emotional exhaustion, the obtained effect sizes were small. It is clear that pharmacists who are burned-out cope with stressful events through mental disengagement, but no clear support was found for previous findings (Maslach \& Jackson, 1982; Rowe, 1997; Schaufeli \& Enzmann, 1998) that individuals who use confronting coping strategies experience less burnout.

Pharmacists who measure high on restraint coping (wait for the optimal opportunity that will reward appropriate action) and positive reinterpretation (accept the reality and manage stress emotions), and low on behavioural disengagement (avoiding problems, losing courage and reacting), tend to experience higher levels of personal accomplishment. They feel able to meet clients' needs and to satisfy essential elements of job performance. These findings confirm the results of Rowe (1997) that withdrawal coping strategies are related to burnout. The use of a problem-focused strategy may trigger feelings of personal accomplishment, which could explain the relationship of confronting coping with personal accomplishment (Lee \& Ashforth, 1996).

The regression formula for predicting emotional exhaustion could be written as follows: Emotional Exhaustion $=49.59-0.27$ (Sense of Coherence) 1.21 (Denial) +1.46 (Mental Disengagement). These variables predict 44 per cent of the variance in emotional exhaustion.

The regression formula for predicting depersonalisation could be written as follows: Depersonalisation $=17.64-0.08$ (Sense of Coherence) -0.36 (Tuming to Religion) $-0.56($ Denial $)+0.59$ (Mental Disengagement) +2.96 (Alcohol- 
Drug Disengagement). These variables predict 35 per cent of the variance in depersonalisation.

The regression formula for predicting personal accomplishment could be written as follows: Personal Accomplishment $=14.46+0.08$ (Sense of Coherence) +1.21 (Positive Reinterpretation and Growth) -0.76 (Behavioural Disengage-ment). These variables predict 41 per cent of the variance in personal accomplishment.

The relationship between coping and burnout should be interpreted carefully for two reasons. Firstly, Folkman and Lazarus (1984) have argued that coping is a state (i.e. situation specific response) rather than a personality trait that is stable across situations. Therefore, correlations between ways of coping and burnout would indicate that burnout is related to particular situations that are perceived as being stressful, which in turn, stimulate, a person to cope in a particular way. Secondly, withdrawal from work or from clients which closely resembles avoidance coping has been regarded as a core symptom of burnout (Chemiss, 1980a). Depersonalisation is also characterised by behaviour that include mental or behavioural withdrawal (Maslach, 1982a). Accordingly, avoidance coping and burnout overlap conceptually.

A limitation of this research is that the research design does not allow one to determine the direction of the relationship between the variables. Another limitation is that a non-probability sample has been used, which implies that the findings cannot be generalised to other settings. The sample size was also relatively small. Also, only self-report measures were used, which may affect the validity of the results.

This study generates several application-oriented suggestions. Firstly, the pharmacy group can select individuals who have a strong sense of coherence and constructive coping strategies. However, before the pharmacy group begins selecting pharmacists on the basis of these characteristics, more research is required, especially because these characteristics were not studied in a selection context. Secondly, the pharmacy group can contribute to the development of pharmacists' sense of coherence by giving information in a consistent, structured, ordered and understandable format. Pharmacists should further be able to identify their roles within the greater whole and as such the comprehensibility component of sense of coherence will be enhanced. 
Thirdly, by equipping pharmacists with the necessary knowledge, skills, material, instruments and other resources, and by ensuring a balance in the load of tasks to be handled, they will increasingly feel that the work expectations are manageable and within their or important others' power. Research indicates that dispositional characteristics that relate to coping styles seem to be subject to change (Lachman, 1989). Therefore, training and development programmes that are directed at developing sense of coherence and coping with stress should be compiled and evaluated.

Future research should focus on individual and organisational factors related to the emotional exhaustion, depersonalisation and lack of personal accomplishment of pharmacists in pharmacy groups. Research is also needed regarding burnout and its possible correlates in other organisational contexts, such as retail pharmacies and public and private hospitals. In future research, objective measures such as performance appraisals and registered absenteeism should be used.

\section{ENDNOTE}

1 Maslach and Jackson (1986).

\section{REFERENCES}

1 ALSOOFI, M.A., AL-HEETI, K.N. \& ALWASHLI, A. (2000) "Burnout and its Relationship with Job Stress and Coping with Stress for Yemeni Teachers", Paper presented at the $28^{\text {th }}$ International Congress of Psychology, Stockholm, Sweden.

2 AMIRKHAN, J.H. (1994) "Criterion Validity of Coping Measures"' Journal of Personality Assessment, 62: 242-61.

3 ANTONOVSKY, A. (1987) "Unravelling the Mystery of Health: How People Manage Stress and Stay Well", San Francisco, CA: Jossey-Bass.

4 ANTONOVSKY, A. (1993) The Structure and Properties of the Sense of Coherence Scale", Social Science and Medicine, 36: 725-33.

5 CALLAN, V.J. (1993) "Individual and Organizational Strategies for Coping with Organizational Change", Work and Stress, 7: 63-75.

6 CARVER, C.S., SCHEIER, M.F. \& WEINTRAUB, J.K (1989) "Assessing Coping Strategies: A Theoretical Based Approach", Journal of Personality and Social Psychology, 56: 267-83.

7 CASH, D. (1988) "A Study of the Relationship of Demographics, Personality, and Role Stress to Burnout in Intensive Care Nurses," Dissertation Abstracts International, 49: 2585A. 
8 CHERNISS, C. (1980a) Professional Burnout in the Human Service Organizations, New York: Praeger.

9 CHERNISS, C. (1980b) Staff Burnout: Job Stress in the Human Services, Beverly Hills, CA: Sage.

10 CLARK, L.A. \& WATSON, D. (1995) "Constructing Validity: Basic Issues in Objective Scale Development", Psychological Assessment, 7 : 309-19.

11 COHEN, J. (1988) Statistical Power Analysis for the Behavioral Sciences (Rev. ed.), Orlando, CA: Academic Press.

12 CORRIGAN, P.W., HOLMES, E.P., LUCHINS, D., BUICAN, B., BASIT, A.J. \& PARKS, J. (1994) "Staff Burnout in a Psychiatric Hospital: A Cross-Lagged Panel Design," Journal of Organizational Behavior, 15: 65-74.

13 DAVIDSON, A.W. (1998) "Challenges of Pharmaceutical Competence in the Global Village", Paper presented at the $3^{\text {rd }}$ International Conference on Pharmaceutical Competence, New South Wales, Australia.

14 DUBRIN, A.J. (1990) Effective Business Psychology ( $3^{\text {rd }}$ ed.), Englewood Cliffs, NJ: Prentice-Hall.

15 FELDT, T. (1997) "The Role of Sense of Coherence in Well-being at Work: Analysis of Main and Moderator Effects, Work and Stress, 11: 134-47.

16 FLANNERY, R.B. \& FLANNERY, G.J. (1990) "Sense of Coherence, Life Stress, and Psychological Distress: A Prospective Methodological Enquiry", Journal of Clinical Psychology, 46: 415-20.

17 FLANNERY, R.B., PERRY, J.C., PENK, W.E. \& FLANNERY, G.J. (1994) "Validating Antonovsky's Sense of Coherence Scale," Journal of Clinical Psychology, 50: 575-7.

18 FLEISHMAN, J.A. (1984) "Personality Characteristics and Coping Patterns", Journal of Health and Social Behaviour, 25: 229-34.

19 FOLKMAN, S. \& LAZARUS, R.S. (1980) "An Analysis of Coping in a Middle-aged Community Sample", Journal of Health and Social Behavior, 21: 219-39.

20 FOLKMAN, S. \& LAZARUS, R.S. (1984) Stress, Appraisal and Coping, New York: Springer.

21 FRENZ, A.W., CAREY, M.P. \& JORGENSEN, R.S. (1993) "Psychometric Evaluation of Antonovsky's Sense of Coherence Scale," Psychological Assessment, 5: 145-53.

22 GILBAR, O. (1998) "Relationship between Burnout and Sense of Coherence in Health Social Workers", Social Work in Health Care, 26(3): $39-49$.

23 GOLEMBIEWSKI, G.T., BOUDREAU, R.A., MUNZENRIDER, R.F. \& LUO, H. (1996) Global Bumout: A Worldwide Pandemic Explored by the Phase Model, Greenwich, CT: JAI Press. 
24 GOLEMBIEWSKI, R.T. \& MUNZENRIDER, R.F. (1988) Phases of Burnout: Development in Concepts and Applications, New York: Praeger.

25 GUPCHUP, G.V., SINGHAL, P.K., DOLE, E.J. \& LIVELY, B.T. (1998) "Burnout in a Sample of HMO Pharmacists Using the Maslach Burnout Inventory", Journal of Managed Care Pharmacy, 4: 495-503.

26 KALIMO, R. \& VUORI, J. (1990) "Work and Sense of Coherence: Resources for Competence and Life Satisfaction", Behavioural Medicine. 16: 76-89.

27 KLEINKE, C.L. (1991) Coping with Life Challenges, San Francisco, CA: Brooks/Cole.

28 KOBASA, S.C. (1982) "The Hardy Personality: Towards A Social Psychology of Stress and Health", In G.S. Sanders \& J. Suls (eds.) Social Psychology of Health and lliness: 3-32, Hillsdale, NJ: Erlbaum.

29 KÜNZEL, R. \& SCHULTE, D. (1986) "'Burn-out' and Reality Shock among Cinical Psychologists," Zeitschrift für Klinische Psychologie, Forschung und Praxis, 15: 303-20.

30 LACHMAN, M.E. (1989) "Personality and Ageing at the Crossroads: Beyond Stability Versus Change", In K.W. Schaie \& C. Schooler (eds.) Social Structure and Ageing: Psychological Processes, Hillsdale, NJ: Erlbaum.

31 LAHOZ, M.R. \& MASON, H.L. (1989) "Maslach Burnout Inventory: Factor Structures and Norms for USA Pharmacists", Psychological Reports, 64: 1059-63.

32 LANDSBERGIS, P.A. (1988) "Occupational Stress among Health Care Workers: A Test of the Job Demands - Control Model", Journal of Organizational Behaviour, 9: 217-39.

33 LEE, R.T. \& ASHFORTH, B.E. (1996) "A Meta-Analytical Examination of the Correlates of the Three Dimensions of Job Burnout", Journal of Applied Psychology, 81: 123-33.

34 LEVERT, T., LUCAS, M. \& ORTLEPP, K. (2000) "Burnout in Psychiatric Nurses: Contributions of the Work Environment and a Sense Of Coherence", South African Journal of Psychology, 30: 36-43.

35 MASLACH, C. (1982a) Burnout: The Cost of Caring. Englewood Cliffs, NJ: Prentice-Hall.

36 MASLACH, C. (1982b) "Understanding Burnout: Definitional Issues in Analysing a Complex Phenomenon", In W.S. Paine (ed.) Job Stress and Burnout: Research, Theory and Intervention. Beverly Hills, CA: Sage.

37 MASLACH, C. \& JACKSON, S.E. (1981) "The Measurement of Experienced Burnout", Journal of Occupational Behaviour, 2: 99-113.

38 MASLACH, C. \& JACKSON, S.E. (1982) "Bumout in Health Professions: A Social Psychological Analysis", In G. Sanders and J. Suls (eds.) Social Psychology of Health and Illness, Hillsdale, NJ: Erlbaum. 
39 MASLACH, C. \& JACKSON, S.E. (1984) "Patterns of Burnout among a National Sample of Public Contact Workers", Journal of Health and Human Resources Administration, 7: 184-212.

40 MASLACH, C. \& JACKSON, S.E. (1986) The Maslach Burnout Inventory (2 $2^{\text {td }}$ ed.) Palo Alto, CA: Consulting Psychologists Press.

41 MASLACH, C., JACKSON, S.E. \& LEITER, M. (1996) Maslach Burnout Inventory: Manual $\left(3^{\text {nd }}\right.$ ed.) Palo Alto, CA: Consulting Psychologists Press.

42 MeSHERRY, W.C. \& HOLM, J.E. (1994) "Sense of Coherence: Its Effects on Psychological and Physiological Processes Prior to, during, and after a Stressful Situation", Journal of Clinical Psychology, 50: 47687.

43 MILLER, K.I., ELLIS, B.H., ZOOK, E.G. \& LYLES, J.S. (1990) "An Integrated Model of Communication, Stress, and Burnout in the Work Place", Communication Research, 17: 200-326.

44 MLONZI, E.N. \& STRÜMPFER, D.J.W. (1998) "Antonovsky's Sense of Coherence Scale and 16PF Second-order Factors", Social Behaviour and Personality, 26: 39-50.

45 MÖLLER, J.S., ROTHMANN, S., COETZER, E.P. \& ROTHMANN, J.C. (2000) "Correlates of Pharmacists' Job Satisfaction and Job Performance", Poster presented at the $4^{\text {th }}$ International Conference on Pharmaceutical Competence, Ottawa, Canada.

46 MOOS, R.H. (1994) "Conceptual and Empirical Advances in Stress And Coping Theory", Paper presented at the $23^{\text {rd }}$ International Congress of Applied Psychology, Madrid, Spain.

47 NUNNALLY, J.C. \& BERNSTEIN, I.H. (1994) Psychometric Theory ( $3^{\text {rd }}$ ed.) New York: McGraw-Hill.

48 ROTHMANN, J.C., ROTHMANN, S., VAN RENSBURG, S. \& MALAN, A.M. (2000) "Linking Personality Preferences, Career Anchors and Job Satisfaction to Pharmacist Development", Poster presented at the $4^{\text {th }}$ International Conference on Pharmaceutical Competence, Ottawa, Canada.

49 ROTHMANN, S. (2000) "Sense of Coherence, Locus of Control and Job Satisfaction", Paper presented at the $27^{\text {th }}$ International Congress of Psychology, Stockholm, Sweden.

50 ROTTER, J.B. (1966) "Generalised Expectancies for Internal Versus Extemal Control of Reinforcement", Psychological Monographs, 80: 128.

51 ROWE, M. (1997) "Hardiness, Stress, Temperament, Coping, and Burnout in Health Professionals", American Journal of Health Behaviour, 21(3): 163-71.

52 SAS INSTITUTE. (1996) SAS Users Guide: Basics (6 ${ }^{\text {th }}$ ed.) Cary, NC: SAS Institute. 
53 SCHAUFELI, W.B. \& ENZMANN, D. (1998) The Burnout Companion to Study and Practice: A Critical Analysis, London: Taylor \& Francis.

54 SCHAUFELI, W.B. \& JANCZUR, B. (1994) "Burnout among Nurses: A Polish-Dutch Comparison", Journal of Cross Cultural Psychology, 25: 95-113.

55 SCHAUFELI, W.B. \& VAN DIERENDONCK, D. (1995) "A Cautionary Note about the Cross-national and Clinical Validity of Cut-off Points for the Maslach Bumout Inventory", Psychological Reports, 76: 1083-90.

56 SEMMER, N. (1996) "Individual Differences, Work Stress and Health", In M.J. Schabracq, J.A.M. Winnubst \& C.L. Cooper (eds.) Handbook of Work and Health Psychology, New York: Wiley.

57 SHAUGINESSY, J.J. \& ZECHMEISTER, E.B. (1997) Research Methods in Psychology ( $4^{\text {th }}$ ed.) New York: McGraw-Hill.

58 STEYN, H.S. (1999). "Praktiese Betekenisvolheid: Die Gebruik van Effekgroottes", Wetenskaplike bydraes - Reeks B: Natuurwetenskappe Nr. 117. Potchefstroom: PU vir CHO.

59 STRUMMPFER, D.J.W. (1990) "Salutogenesis: A New Paradigm", South African Journal of Psychology, 20: 265-276.

60 STRÜMPFER, D.J.W. (1995) "The Origins of Health and Strength: From 'Salutogenesis' to 'Fortigenesis"', South African Journal of Psychology, 25: 81-9.

61 TYLER, P. \& CUSHWAY, D. (1998) "Stress and Well-being in Healthcare Staff: The Role of Negative Affectivity, and Perceptions of Job Demand and Discretion", Stress Medicine, 14:99-107.

62 ZEIDNER, M. \& ENDLER, N.S. (1996) Handbook of Coping: Theory, Research, Applications, New York: Wiley. 